\title{
Fishing For Fishbone in Neck
}

\author{
Sabari Nath HS ${ }^{1 *}$, Jayakumar R Menon ${ }^{2}$, Manju E Issac ${ }^{3}$, Meera Gopal ${ }^{4}$ and Greeshma K Menon ${ }^{4}$ \\ ${ }^{1}$ Assistant Professor, Department of ENT \& Laryngology, Azeezia Medical College, India \\ ${ }^{2}$ Senior Consultant, Department of Laryngology, Kerala Institute of Medical Science, India \\ ${ }^{3}$ Associate Consultant, Department of Laryngology, Kerala Institute of Medical Science, India \\ ${ }^{4}$ Resident, Department of ENT, Kerala Institute of Medical Science, India \\ Submission: February 11, 2017; Published: February 28, 2017 \\ *Corresponding author: Sabari Nath HS, Department of ENT, Azeezia Medical College, kollam, Kerala, India, Email: dr.sabarinath@icloud.com
}

\begin{abstract}
Accidental swallowing of Fishbone is very common in Fish eating communities. Usually the swallowed fishbone pass down the gastrointestinal tract or can be removed without much difficulty as office procedure or via endoscopically. Here we have three cases of migrating foreign bodies, in the last six months which required neck exploration for its removal.
\end{abstract}

Keywords: Foreign Body Throat; Migrating Foreign Body; Neck Exploration; Failed Endoscopic Removal Of Foreign Body; Fish Bone

\section{Introduction}

Accidental swallowing of fishbone is very common in fish eating communities and usually the swallowed bone will be small or soft and will pass down the gastrointestinal tract without causing any problems [1,2]. A wide variety of foreign bodies were retained in the esophagus with fish bones being the most common $(60 \%)$ and chicken bones the second most common (16\%) [3]. Esophageal penetration resulting from foreign body ingestion is uncommon, with an incidence report between $1 \%$ and $4 \%$ [3]. Fishbone or similar foreign bodies can stuck in the throat or penetrate the pharynx, oesophagus or stomach causing retropharyngeal abscesses, mediastinal abscesses, or even penetrating the pericardium causing cardiac tamponade ,aortic or GI perforation or septic complications [410]. We are reporting three cases of fishbone penetrating the gastroesophagial tract which were removed by neck exploration.

The Cases

\section{CASE: 1}

A 70-year-old gentleman from the coastal district of Tamilnadu was referred to our centre, with complaints of neck pain since 1 week. He gives a history of ingestion of fish, following which symptoms started. Evaluated in a local hospital and CT scan was suggestive of a linear foreign body at the level of C4 involving retropharyngeal tissue. On examination of throat, there was a bulge in the posterior pharyngeal wall on left side, laryngeal crepitus was abscent, laryngeal elevation was normal, Respiratory rate 16 with no signs of stridor. No history of any fever. No foreignbody visualized in direct examination of throat. The patient was swallowing fluids and solids normally. X-ray soft tissue of the neck did not show any foreign body but was suggestive of retropharyngeal abscess.

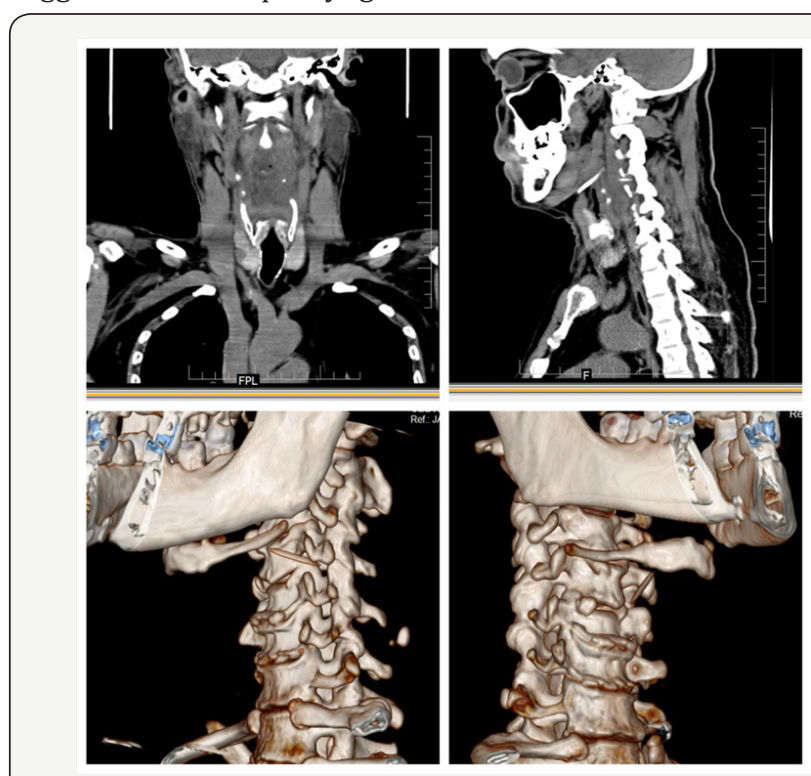

Figure 1: Computed Tomography and 3 D Reconstruction showing the foreign body. 
So a 64 slice computed tomogram was taken which showed a dense foreign body measuring $0.2 \times 2.5 \mathrm{~cm}$ in the retropharyngeal soft tissue towards the left, which was oriented horizontally and postero inferiorly and the distal end abuts the C5 transverse process. It was seen just lateral to the left vertebral artery at C5 level. Prevertebral soft tissue was thickened $(6.6 \times 1.4 \mathrm{~cm})$ and showed air pockets within and extending from $\mathrm{C} 2-\mathrm{C} 7$, which was causing mass effect on the oropharynx causing mild narrowing of the lumen and compresses the left pyriform fossa. An MRI with contrast of the cervical spine was taken and it showed edema of the prevertebral tissues with effacement of supraglottic airway and left vertebral artery showed normal flow void and flow related enhancement (Figure 1).

In this case the patient was fortunate in that the fishbone did not penetrate into vertebral artery or other vital structure and no deep infection developed. He was taken up for foreignbody removal with neck exploration. A linear incision was put in the midline of neck corresponding to the mid thyroid ala portion along the natural skin crease. Flap raised superiorly. Strap muscles cut on the left side after midline split. Pyriform fossa exposed. Lateral to the pyriform fossa, in the prevertebral area a sharp object palpated and was removed using forceps after split opening the mucosa above it.

\section{CASE: 2}

A 71 year old gentleman presented in the emergency room with history of difficulty in swallowing since 2 days. He gave a history of ingestion of mango pickle, which was stuck in his throat. He didn't give any history of fish/chicken ingestion. No history suggestive of stricture esophagus. X-Ray neck was taken and it didn't revealed any opaque foreign body, except for air behind the trachea. A flexible nasopharyngolaryngoscopy was done and it showed pooling of secretions, edema of bilateral arrytenoids and secondary penetration and aspiration.
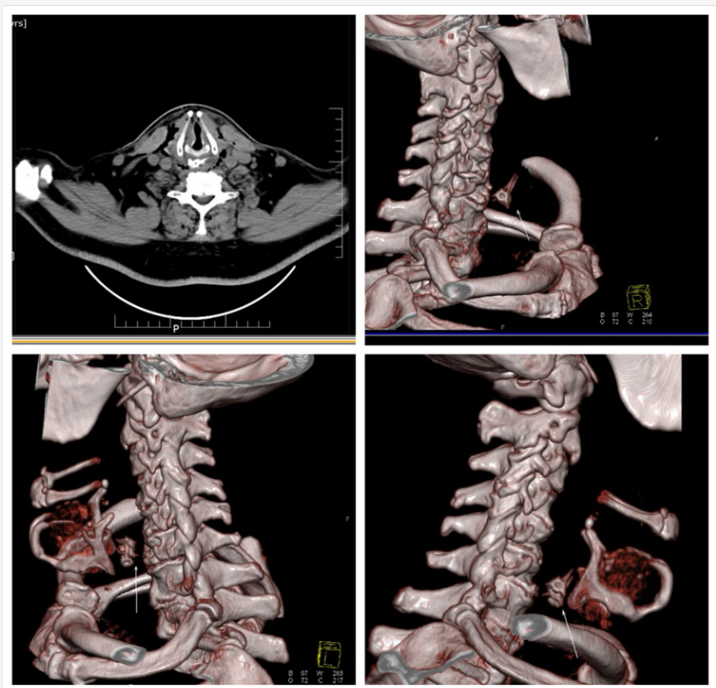

Figure 2: Computed Tomography and \#D reconstruction showing fish bone behind the cricoids cartilage.
He was taken up for rigid esophagoscopy and foreign body removal under general anaesthesia. On esophagoscopy no foreign body was visualized except for an ulceration in the area of cricopharynx. As no foreign body was visualized till lower esophageal sphincture and the patient didn't gave any history of fish/chicken ingestion we assumed that the foreign body (mango pickle as per history) has gone down on giving muscle relaxant and the ulcer seen in the area of cricopharynx may be due to chemical esophagitis caused by pickle. But the patient continued to have absolute dysphagia on second post operative day also. So a repeat flexible nasopharyngolaryngoscopy was done and it showed same features as in previous scopy. So a computed tomogram of neck was taken which showed soft tissue thickening with multiple air pockets noted in prevertebral area extending from nasopharynx to C7 vertebra. Opaque foreign body was noted in the area of C5-C6 vertebral level (Figures 2-4).

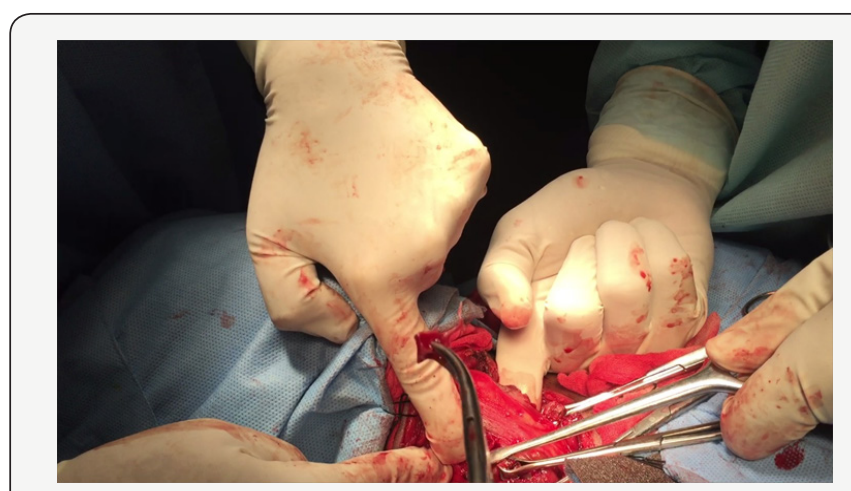

Figure 3: Computed Tomography and \#D reconstruction showing fish bone behind the cricoids cartilage.

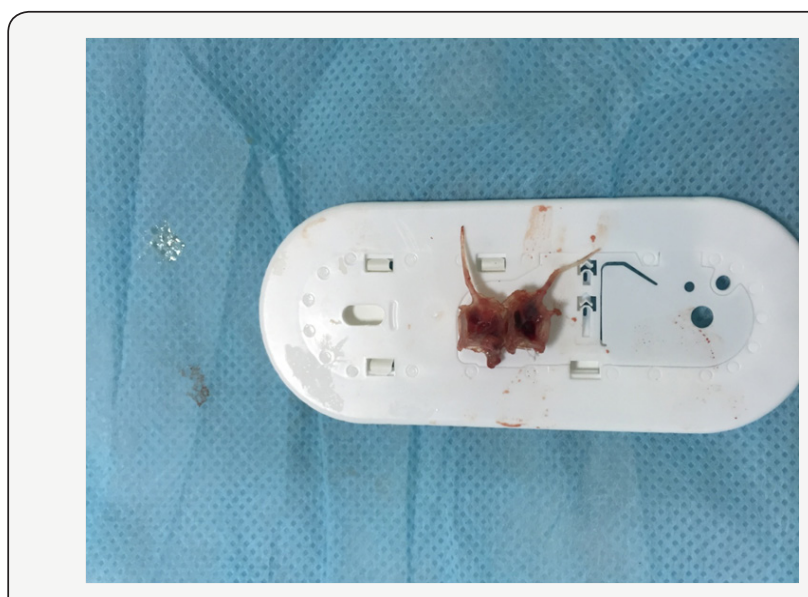

Figure 4: Removed huge fishbone with vertibra.

History was again elicited, and bystanders gave a history of consuming fish, which the patient didn't agree initially. He was again taken up for rigid esophagoscopy under GA with C-Arm guidence. An opaque foreign body was visualized in the cricopharyngeal area which was corresponding to the area of ulcer in cricopharynx. Hence on table we decided to do a neck exploration. Kochers collor incision put, Flaps raised, midline split done. Sternomastoid dissection in anterior part. 
Strap muscles cut. Sharp object palpated in the posterior part of the cricoid cartilage inside the muscle which was removed after split opening the muscle fibres. Ryles tube was put and a tracheostomy done as prophylaxis.

\section{CASE: 3}

A 69 year old gentleman was referred to our centre with difficulty in swallowing since 7 days, severe pain while swallowing since 1 day. He gave a history of foreign body throat, fishbone 7 days back. This was shown to a local hospital and was treated with antibiotics and pain killers. Transnasal esophagoscopy was done and slough was found just below the apex of right pyriform fossa. A computed tomogram was taken and it revealed a large $\mathrm{V}$ shaped opaque foreignbody probably fishbone in the retropharyngeal space posterior to thyroid lamina on right side (Figure 5).
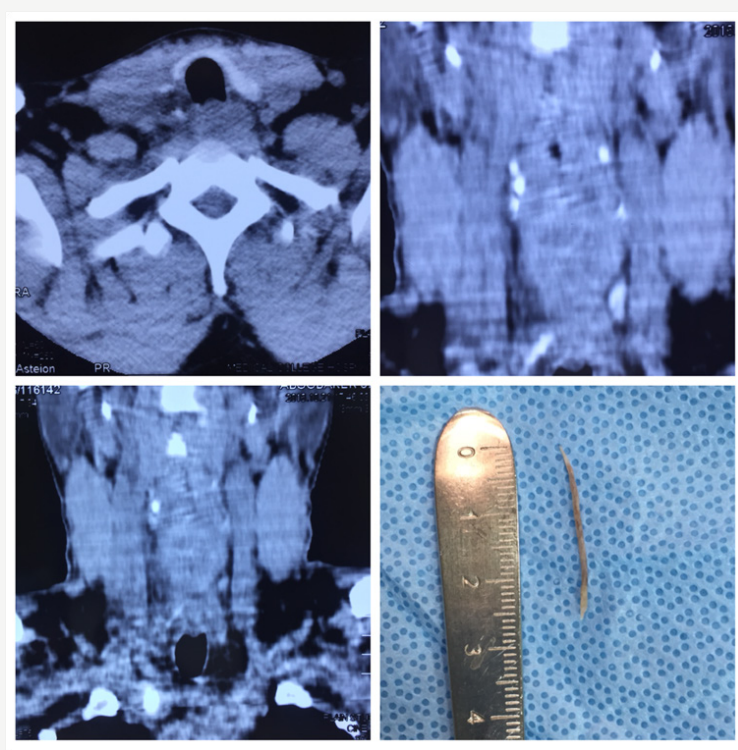

Figure 5: CT image along with the foreign body (fish bone) removed by neck exploration.

He was takenup for rigid esophagoscopy and foreign body removal under general anaesthesia. On rigid esophagoscopy also only slough was visualized in the area just below the apex of the right pyriform fossa. Scopy was again attempted with C-arm guidance. An opaque shadow suspicious of foreign body was visualized in the deeper tissue in the area of slough, but couldn't remove or palpate the foreign body, hence decided to explore neck. Neck exploration was done and fishbone removed from cricopharynx and the pyriform fossa deficit repaired and he was removed on $12^{\text {th }}$ postop day after fluoroscopic evaluation

\section{Discussion and Conclusion}

Most ingested fishbones can pass through the gastrointestinal tract without complication. However, some may impact in the esophagus, mostly at the level of the cricopharyngeus muscle and the aortic arch in the cervical and thoracic esophagus [2]. Perforation occurs in $1 \%$ to $4 \%$ of patients, and impacted esophageal fishbone must be removed as soon as possible $[1,2]$. The mechanism of fish bones associated with esophageal perforation is thought to be initial impaction and then a combination of local inflammation of the esophageal wall and direct pressure necrosis. The most common site of foreign body impaction in the esophagus is the cervical esophagus at the level of the cricopharyngeus, followed by the thoracic esophagus at the level of the aortic arch [11]. Perforation of the esophagus by a foreign body usually results in a dramatic clinical picture characterized by odynophagia, dysphagia, respiratory distress, vascular injury and fever [12].

The forces driving a foreign body through the wall of the oesophagus and the forces directing its passage to the ultimate site need some consideration.

a) The intraluminal pressure in the oesophagus may force a transverse or oblique positioned sharp foreign body through the wall of the gut.

b) The site of penetration in the oesophagus may play a role in the track of movement and site of settlement.

c) A foreign body under the forces of gravity and pressure in the surrounding tissues tends to move towards planes of least resistance, and like pus, will find its way out.

$\mathrm{X}$ ray, especially routine exposures, does not always help detect a relatively delicate object such as a fishbone. An ultrasound study of the neck and intraoesophageal probe may yield better results. When patients present with persistent complaint of a foreign body sticking in the throat or oesophagus, the physician should conduct a direct examination of the pharynx and oesophagus and even the stomach, to trace the foreign body and check for the site of penetration, and take all possible measures to retrieve the object. Computed tomogram with or without contrast is having a high value in pickingup foreignbodies which penetrate the normal tract.

In all the three cases patients were around the age of 70. All three of them had consumed alcohol on the day of incident. In geriatric population dysphagia is on the rise. Along with the age alcohol may also have contributed for the complication, because of poor sensation and delay in reporting to the surgeon. Two out of the three cases were reported 1 week after the incident and the other one being on $2^{\text {nd }}$ day.

\section{References}

1. Ngan JH, Fok PJ, Lai EC, Branicki FJ, Wong J (1989) A prospective study on fish bone ingestion. Experience of 358 patients. Ann Surg 211(4): 459-462.

2. Girish Bathla, Lynette LS Teo, Sunita Dhanda (2011) Pictorial essay: complications of a swallowed fish bone. Indian J Radiol Imaging 21(1): 63-68.

3. Scher RL, Tegtmeyer CJ, McLean WC (1990) Vascular injury following foreign body perforation of the esophagus: review of the literature and report of a case. Ann Otol Rhinol Laryngol 99(9 Pt 1): 698-702. 
4. Polcrová A, Wiedermann J, Vomácka J (1990) Foreign bodies in the deglutition tract and their complications. Cas Lek Cesk 129(15): 467468 .

5. Swoniski H, Gracz J (1983) Foreign bodies in the retro pharyngeal space. Otolaryngol Pol 37: 59-61.

6. Bizakis JG, Sega J, Skoulakis H, Voludakis A, Velegrakis G, et al. (1993) Retropharyngoesophageal abscess associated with a swallowed bone. Am J Otolaryngology 14(5): 354-357.

7. Janecka V (1973) Voluminous retropharyngo-esophageal abscesses resulting from neglected foreign bodies (fish bones) in the hypopharyngo-esophageal region. Cesk Otolaryngol 22(1): 49-52.

8. Mateo S, Blazquez C, Ortega J, Cabajo M, Hernandez M, et al. (1984) Mediastinal abscess secondary to esophageal perforation caused by foreign body. Med Cli (Barc) 82(17): 779-780.

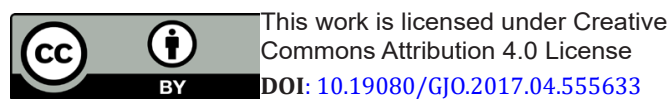

9. Sharland MG, McCaughan BC (1993) Perforation of the esophagus by fish bone leading to cardiac temponade. Ann Thorac Surg 56(4): 969971.

10. Roberts, James R (2001) Fish Bones in the Throat. Emergency Medicine News 23(8): 7-8.

11. Nandi P, Ong GB (1978) Foreign body in the esophagus: review of 2394 cases. Br J Surg 65(1): 5-9.

12. Hsin-Hui Chiu, Joe Hergens Li, and Jin-Sheng Chen (2006) Penetration of Esophageal Wall by A Fish Bone. J Intern Med Taiwan 17: 298-301.

\section{Your next submission with Juniper Publishers will reach you the below assets}

- Quality Editorial service

- Swift Peer Review

- Reprints availability

- E-prints Service

- Manuscript Podcast for convenient understanding

- Global attainment for your research

- Manuscript accessibility in different formats

( Pdf, E-pub, Full Text, Audio)

- Unceasing customer service

Track the below URL for one-step submission https://juniperpublishers.com/online-submission.php 